\title{
An Analysis of Cultural Tourism Cluster: The Case of Aksaray Province
}

\author{
Muhammet Saygin (Aksaray University, Turkey) \\ Himmet Karadal (Aksaray University, Turkey)
}

\begin{abstract}
A business cluster is a geographic concentration of interconnected businesses, suppliers, and associated institutions in a particular field. Clusters are considered to increase the productivity with which companies can compete, nationally and globally, so the cluster arises because it provides the increase of productivity and innovation abilities; for this reason its development should be supported not only by central governments but also by the local authorities. It is a known fact that tourism, one of the most effective aims for development, is considered to be a leading factor in cultural, economical and social perspectives through cluster types. In this study, the potential of cultural tourism cluster and competitiveness of Aksaray province has been analyzed in terms of Porter's Diamond Model. Several data sources including strategic development plan and academic literature have been taken into consideration. In this regard, findings about whether there is really a tourism cluster in Aksaray province have been stated and recommendations have been suggested to empower the innovative advantage of cultural tourism cluster.
\end{abstract}

JEL Codes: O10, O12

\section{Introduction}

Tourism is considered to be a leading factor in cultural, economical and social perspectives. It creates the development climate for the nations. Although it has significant effects for the nations, development process of the tourism is thought to be started in regional conditions. As Opperman (1993) pointed out that if tourism importance is significant at a national level, at a regional level this sector is presented as an essential tool in regional development and economic growth, believing to be one of the weapons to avoid desertification and regions economic stagnation, namely in the inner regions. This research is structured as follows: it is designs a literature background which allows defining and explaining a number of concepts related to the clusters, in particular of tourism, in terms of many researchers' point of view. Then it presents some evidences about regional development samples and lastly it includes the adaptation of Porter's Diamond Model of Aksaray Province. It also tries to present a conceptual model of regional competitiveness of a tourism cluster which is aiming to help filling the gap within this field besides the providing a possible tool fort he next studies about the regional development processes for the other cities in Turkey.

The overall purpose of this study is to emphasize the importance of clusters within tourism sector. It aims to provide an understanding that clusters not only provide an opportunity of economic development, but also a higher level of innovation and an increased competitiveness to the tourism sector. In this study, the potential of cultural tourism cluster and competitiveness of Aksaray province is analyzed. Several data sources including strategic development plans and academic literature have been taken into consideration. In this regard, findings about whether there is really a tourism cluster in Aksaray province are stated and recommendations are suggested to empower the innovative advantage of cultural tourism cluster.

\section{Theoretical Framework}

There are many studies dealing with the clusters, tourism and innovation in the world, but as a tourism paradise, Turkey still has a few academic works about these concepts. In today's world, innovation is the key concept for the development in each field, so it is obviously vital that innovation should be clarified before dealing with the clusters. The term innovation derives from the Latin word innovatus, which is the noun form of innovare "to renew or change," stemming from in-"into" + novus-"new". Although the term is broadly used, innovation generally refers to the creation of better or more effective products, processes, technologies, or ideas that affect markets, governments, and society. Innovation differs from invention or renovation in that innovation generally signifies a substantial change compared to entirely new or incremental changes (URL 1). Innovation is not an activity of a single business; it requires an active search involving several firms to tap new sources of knowledge and technology and apply these in products and production processes. In many countries, clusters of innovative firms are driving growth and employment. Innovative clusters of economic activity are becoming magnets for new technology, skilled personnel and research investment. These groups of enterprises tend to be well established and stable, innovating through strong backward and forward linkages with suppliers and customers. Co-operation in clusters has increasingly become a requirement for success. Moreover, co-operation offers a direct way to improve economic performance and reduce costs (OECD, 1999). According to Porter 
(1998), "In theory, location should no longer be a source of competitive advantage. Open global markets, rapid transportation, high speed communications should allow any company to source any thing from any place at any time." This may be absolutely true, but in today's world, locations lose their importance because of the use of information technologies, but locations are also the key concept for providing competitive advantages. The cluster term indicates that businesses grow in certain regions as opposed to others for other reasons than pure economical factors. It highlights the importance of research and innovation as well as access to skilled workforce, quality education and investment capital (Nordin, 2003). The cluster concept focuses on the linkages and interdependencies among actors in the value chain in producing products and services and innovating. Clusters differ from other forms of co-operation and networks in that the actors involved in a cluster are linked in a value chain. The cluster concept goes beyond "simple" horizontal networks in which firms, operating on the same end-product market and belonging to the same industry group, co-operate on aspects such as R\&D, demonstration programmes, collective marketing or purchasing policy (OECD, 1999). Clusters are used to represent concentrations of companies, so that they can produce synergy, through their geographical proximity and their interdependence (Rosenfeld, 1997). Feser (1998) points out those economic clusters don't refer only to industries and institutions, but to the highly competitive industries and institutions. This competitiveness is because of the relations between them. An innovative cluster is defined as a large number of inter-related industries with a high degree of collaboration, and that operates in the same market with the same characteristics (Simmie and Sennett, 1999). Clusters are important for competition since they increase productivity, they direct the path of innovation and stimulate the formation of new businesses, in addition, the geographical concentration allow companies to operate with greater productivity in the search for inputs such as specialized labour and specialized machinery and components suppliers, aside from facilitate access to information and technology. Tourism cluster is a geographic concentration of companies and institutions interconnected in tourism activities. This includes suppliers, services, governments, institutions, universities and competitors (Capone, 2004). According to Ferreira (2003) tourism cluster includes, in addition to the activities considered in the tourism sector, namely accommodation, catering, entertainment and various attractions, operators and travel agencies, guides, crafts, car rentals and touristic transport, other services and related and support activities, like organizations and support services, transport infrastructure, education and training, consultancy and other business services. We can verify that there are no substantial differences between the cluster's definition in a general scope, and the cluster's concept when applied to the tourism industry. The tourism cluster, as clusters in general, is defined as a geographical concentration in a region of companies and institutions inter-related. According to Jackson and Murphy (2002), the very governments are who identify tourism as a possible way to achieve economic development given the employment scarcity in the traditional sectors of economy. According to Botti et al. (2008), geographical proximity plays an important role in the perception of the performance of tourism organizations, in order to maintain the survival of tourism businesses and contribute to the competitiveness of the tourism sector. According to Botti et al. (2008), geographical proximity plays an important role in the perception of the performance of tourism organizations, in order to maintain the survival of tourism businesses and contribute to the competitiveness of the tourism sector.

\section{Findings}

Launched in March 2007, "Development of a National Clustering Policy" is an EU-funded technical assistance project that seeks to contribute to elaboration of a national clustering policy through development of a whitepaper on clustering. The Project has been implemented by the under secretariat for Foreign Trade with the technical assistance of an international consortium. The Project was composed of three components: institution building, policy development, a cluster mapping. The project involved ten cities in Turkey, but unfortunately Aksaray was not involved in this cluster list.

In 2011, Aksaray province strategical development plan has been developed by supports of the academicians, politicians, businesses and volunteers. According to this report, tourism sector in Aksaray province is not a cluster example but shows the potential of cultural tourism clustering. Especially, centre of the town, Ihlara and Monastery Valley, Güzelyurt, and Gülağaç have the potential of cultural tourism cluster. Table 1 illustrates the numbers of visitors and we may imply the potential of cultural tourism of the province.

\begin{tabular}{|l|c|c|c|c|c|c|}
\hline & \multicolumn{3}{|c|}{ Number of the Visitors } & \multicolumn{3}{c|}{ Occupancy } \\
\hline & Foreigner & Native & Total & Foreigner & Native & Total \\
\hline Aksaray & 5582 & 34439 & 40021 & 2,32 & 12,72 & 15,03 \\
\hline Kırıkkale & 47 & 11277 & 11324 & 0,15 & 31,86 & 32,02 \\
\hline Kırşehir & 73 & 9755 & 9828 & 0,09 & 43,93 & 44,02 \\
\hline Nevşehir & 80136 & 173396 & 253532 & 5,37 & 7,39 & 14,77 \\
\hline Niğde & 3364 & 33985 & 37349 & 4,14 & 47,06 & 51,20 \\
\hline Turkey & 4115212 & 11468804 & 15584016 & 13,32 & 15,57 & 28,89 \\
\hline
\end{tabular}

Table 1: Number of the visitors in terms of the cities 
As it is indicated in this report, the most significant tourism cluster examples are given as İstanbul, Cappadocia, Antalya, Muğla, İzmir, Beypazarı, Safranbolu and Bursa. From this point of view, Aksaray province which has a high potential of cultural tourism potential at the regional level should be analyzed in terms of the Porter's Diamond Model. This model includes determinants of national advantage. In his famous study, The Competitive Advantage of Nations, Porter (1990) indicates that;

- Factor conditions can be thought as human resources, physical resources, knowledge resources, capital resources and infrastructure etc. They also include factors like quality of research on universities, deregulation of labour markets, or liquidity of national stock markets. It is pointed out that these factors are not necessarily nature-made or inherited.

- Demand conditions can help businesses create a competitive advantage. These conditions have impact on the direction of innovation and product development.

- Related and supporting industries create the view of existence or non-existence of internationally competitive supplying industries and supporting industries. These industries can produce inputs which are important for innovation and internationalization.

- Firm strategy, structure and rivalry terms imply the conditions in a country and characteristics of domestic competition. They constitute the fourth determinant of competitiveness. The way in which companies are created, set goals and are managed is important for success.

\begin{tabular}{|c|c|c|}
\hline $\begin{array}{c}\text { Diamond } \\
\text { Model }\end{array}$ & Advantages & Disadvantages \\
\hline $\begin{array}{c}\text { Factor } \\
\text { Conditions }\end{array}$ & $\begin{array}{l}\text {-Closeness to Cappadocia region } \\
\text {-Closeness to religious tourism areas like } \\
\text { Konya and Kayseri } \\
\text { - Presence of Ihlara and Monastery Valleys } \\
\text {-Presence of many historical artefacts for } \\
\text { religious tourism } \\
\text {-Confluence point for the big cities: Konya, } \\
\text { Kayseri, Ankara } \\
\text { Presence of potential for the cultural, winter, } \\
\text { religious tourism }\end{array}$ & $\begin{array}{l}\text {-Absence of vocational courses and in- } \\
\text { service training seminars about tourism } \\
\text {-Airport is an hour away } \\
\text {-University-tourism cooperation is not } \\
\text { sufficient } \\
\text {-Unwillingness of the businesses for } \\
\text { establishing a web of relationships at the } \\
\text { national and regional scale. } \\
\text {-Absence of a planning for provincial } \\
\text { coordination }\end{array}$ \\
\hline $\begin{array}{c}\text { Demand } \\
\text { Conditions }\end{array}$ & $\begin{array}{l}\text {-Being in the middle of Turkey } \\
\text {-Developing relations with the Middle East. } \\
\text {-Close cultural relations with Arab and } \\
\text { Islamic Regions. } \\
\text {-Increasing demand for the cultural and } \\
\text { religious tourism in the world and in our } \\
\text { country }\end{array}$ & $\begin{array}{l}\text {-Less qualified accommodation and catering } \\
\text { facilities } \\
\text {-Lack of travel agencies working in the } \\
\text { region } \\
\text {-Ihlara Valley being not included in The } \\
\text { World Heritage List } \\
\text {-Monastery Valley being not included in The } \\
\text { World Heritage List } \\
\text {-Facilities of Hasan Mountain has not been } \\
\text { completed }\end{array}$ \\
\hline $\begin{array}{l}\text { Firm } \\
\text { Strategy, } \\
\text { Structure, } \\
\text { and Rivalry }\end{array}$ & $\begin{array}{l}\text {-Existence of potential for cultural tourism } \\
\text { - Initial investment and operating costs for } \\
\text { investors in the tourism industry are more } \\
\text { attractive than other sectors } \\
\text {-The presence of small and medium-sized } \\
\text { businesses in the hospitality industry and their } \\
\text { susceptibility to co-operation } \\
\text {-unique opportunities for cultural tourism in } \\
\text { terms of pensioning }\end{array}$ & $\begin{array}{l}\text {-Underdeveloped entrepreneurial culture } \\
\text {-New markets' underdeveloped research } \\
\text { culture } \\
\text {-The problem of institutionalization, } \\
\text {-Cooperation among firms is } \\
\text { underdeveloped } \\
\text {-The scale problem } \\
\text {-Underdeveloped marketing and branding } \\
\text { skills on the basis of destinations }\end{array}$ \\
\hline $\begin{array}{l}\text { Related and } \\
\text { Supporting } \\
\text { Industries }\end{array}$ & $\begin{array}{l}\text {-Closeness to Cappadocia region } \\
\text {-Strong potential of cultural tourism as well as } \\
\text { winter tourism, city tourism, rural tourism and } \\
\text { spa tourism }\end{array}$ & $\begin{array}{l}\text {-City tourism infrastructure } \\
\text {-Rural tourism infrastructure } \\
\text {-Winter tourism infrastructure } \\
\text {-Thermal tourism infrastructure }\end{array}$ \\
\hline $\begin{array}{l}\text { The Role of } \\
\text { Government }\end{array}$ & $\begin{array}{l}\text {-The presence of incentives } \\
\text {-The strong co-ordination -between the } \\
\text { Ministry of Culture and Tourism, the } \\
\text { Governor, Chamber of Commerce and the } \\
\text { University for the development of tourism } \\
\text { studies }\end{array}$ & $\begin{array}{l}\text {-Lack of region-specific tourism incentives } \\
\text {-Lack of communication between local } \\
\text { agencies and the private sector } \\
\text {-Government incentives are not adequate }\end{array}$ \\
\hline
\end{tabular}

Table 2. Diamond model analysis 
- Government can influence each of the above four determinants of competitiveness. Clearly government can influence the supply conditions of key production factors, demand conditions in the home market, and competition between firms.

Porter's diamond model suggests that there are inherent reasons why some nations, and industries within nations, are more competitive than others on a global scale. As it can be seen in the Table 2, there are many advantages as well as disadvantages for Aksaray in terms of cultural tourism clusters. Factor conditions indicate that this province is in the middle of Turkey and very close to other Cultural tourism centres as Cappadocia and Konya. Also its adjacent provinces are Niğde to the southeast and Kirşehir to the north and of course Nevşehir to the east. The absence of vocational courses and in-service training seminars about tourism sector and absence of a close airport besides the non-sufficient cooperation and unwillingness of businesses occur as the disadvantages of this province. Also the lack of planning for the provincial conditions makes us think about the negative sides.

Fortunately, this is a region of great natural beauty and Aksaray is one of the four much-visited provinces in the area of Cappadocia, along with Nevşehir, Niğde and Kayseri. Also the 3,000 m volcano Mount Hasan stands between Aksaray and Niğde. The $2400 \mathrm{~km}^{2}$ salt lake, lies within the boundaries of Aksaray, a large area of swamp with a maximum depth of 1 meter. Having the important historical places like Aşıklı Höyük, a burial mound 25 $\mathrm{km}$ east of the city, Acemhöyük, an early Bronze Age settlement, which is $18 \mathrm{~km}$ north-west of the city, the ancient city of Nora and a great number of historical mosques and churches in Ihlara Valley. Besides that, advantages and disadvantages of the city are indicated and differences in terms of the factor conditions, demand conditions, firm strategy, structure, and rivalry, related-supporting industries and the role of government can easily be seen in the figure 1 (Barca and Others, 2011).

\section{Conclusion}

Tourism is the leading factor of development for the countries. It not only creates the appropriate climate but also serve as a regional opportunity, but in today's world only tourism is not the key of success, it should be combined with other processes. For example, people in the sector should follow the technological chances and deal with the innovations. They should pursue their dreams. Otherwise if the sector remains still while the world is changing, there is no doubt that there won't be any improvements. So, tourism concept should be dealt with the cluster term which is the concentration of interconnected businesses within the same sector. In this study, potential of cultural tourism cluster and competitiveness of Aksaray province has been analyzed. Strategic development plan of the city which was carried out in 2011 and other academic studies have been presented in order to prove the potential of cultural tourism. Also, Porter's Diamond Model was applied for the city, advantages and disadvantages for different condition types have been given. Findings about if there is really a tourism cluster in Aksaray province have been tried to be stated, so it is concluded that there is a great potential but it can not be said that there is cluster tendency actually. In this regard, findings show us that the city is in the middle of the country and this makes the transportation easy. Also developing relations with the Middle East close cultural relations with Arab and Islamic Regions and increasing demand for the cultural and religious tourism in the world and in our country show the potential of cultural tourism and indicate the need for clusters. Though the absence of vocational courses and in-service training seminars about tourism sector and absence of a close airport besides the non-sufficient cooperation and unwillingness of businesses occur as the disadvantages and the lack of planning for the provincial conditions makes us think about the negative sides, but they are not the insoluble problems. In addition to the results of the study, recommendations should be given. In this respect, we believe that except for the written studies, there should be digital information supplies giving information about the beauties of the region because this is the region of great natural beauty and Aksaray is one of the four much-visited provinces in the area of Cappadocia. Having the important historical places like Aşılı Höyük, Acemhöyük, the ancient city of Nora and a great number of historical mosques-churches in Ihlara Valley, the potential of cultural tourism is increased. Furthermore, people dealing with the tourism sector should know the effects of information technologies and of course the internet. What is implied here is that tourism sector needs to people who have internet knowledge urgently. These people will bring both necessary know-how and dynamism to the sector. 


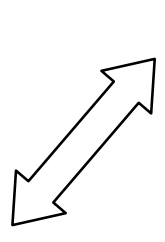

Demand

Conditions

Advantages

*Being in the middle of Turkey,

*Developing relations with the Middle East,

*Close cultural relations with Arab and Islamic

Regions,

*Increasing demand for the cultural and religious tourism in the world and in our country.

\section{Disadvantages}

*Less qualified accommodation and catering facilities, *Lack of travel agencies working in the region,

*Ihlara Valley being not included in The

World Heritage List,

*Monastery Valley

being not included

in The World

Heritage List,

*Facilities of

Hasan Mountain

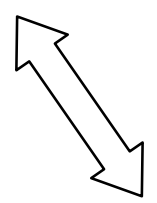

\section{Factor Conditions}

\section{Advantages}

*Closeness to Cappadocia region, *Closeness to religious tourism areas like Konya and Kayseri, *Presence of Ihlara and Monastery Valleys, *Presence of many historical artifacts for religious tourism, ${ }^{*}$ Confluence point for the big cities: Konya, Kayseri, Ankara, ${ }^{*}$ Presence of potential for the cultural, winter, religious tourism.

\section{Disadvantages}

*Absence of vocational courses and inservice training seminars about tourism, *Airport is an hour away, *Universitytourism cooperation is not sufficient, *Unwillingness of the businesses for establishing a web of relationships at the national and regional scale, *Absence of

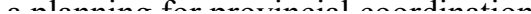

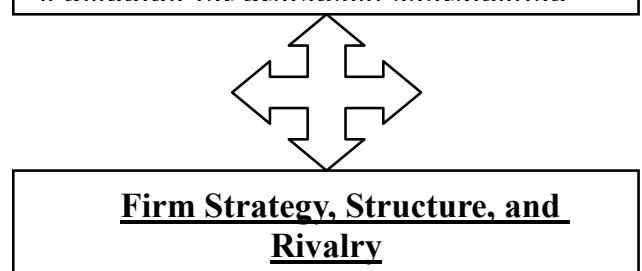

\section{Advantages}

*Existence of potential for cultural tourism, *Initial investment and operating costs for investors in the tourism industry are more attractive than other sectors, *The presence of small and medium-sized businesses in the hospitality industry and their susceptibility to co-operation*Unique opportunities for cultural tourism in terms of pensioning.

\section{Disadvantages}

*Underdeveloped entrepreneurial culture, *New markets' underdeveloped research culture, ${ }^{*}$ The problem of institutionalization, *Cooperation among firms is underdeveloped, *The scale problem *Underdeveloped marketing

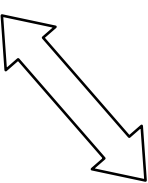

\section{$\underline{\text { Related and }}$ Supporting $\underline{\text { Industries }}$}

\section{Advantages}

*Closeness to Cappadocia region,

*Strong potential of cultural tourism as well as winter tourism, city tourism, rural tourism and spa tourism.

\section{Disadvantages}

*City tourism infrastructure

*Rural tourism infrastructure

*Winter tourism infrastructure

*Thermal tourism infrastructure

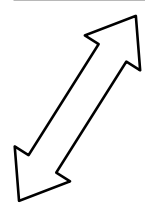

Figure 1: Diamond Model of Aksaray Cultural Tourism

\section{References}

- BARCA, M., KARADAL H., HIZIROĞLU M., GÜLÇUBUK, B., GÜNDOĞGU, G., HIZIROĞLU, A., DÖVEN, M.S., SERTER, G. and DEMIREL, A.Z. (2011). Aksaray İli Ekonomik Kalkınma Araştırma Raporu, (unpublished study), Aksaray.

- $\quad$ BOTTI, L., CAMPRUBI, R. and TORRÈS, O. (2008). "Tourism and Regional Development: Small Businesses and Social Network for Competitiveness", Research Entrepreneurship and Small Business XXII, Universidad Beira Interior, Covilhã.

- CAPONE, F. (2004). "Regional Competitiveness in Tourism local Systems", 44 European Congress of the European Regional Science Association, Regions and Fiscal Federalism, Universidad the Porto.

- FERREIRA, M., (2003). "Estratégia e Planeamento Regional do Turismo", Investigação em Turismo - Livro de Actas, pp. 67-82. 
- $\quad$ FESER, E. (1998). "Old and New Theories of Industry Clusters", in Steiner, M. (1998), Cluster and Regional Socialization: On Geography, Technology and Networked, Londres, Pion, pp. 18-40.

- JACKSON, J. and MURPHY, P. (2002). “Tourism Destinations as Clusters: Analytical Experiences From The New World", Tourism and Hospitality Research, Vol.4, No1, pp. 36-52.

- $\quad$ NORDIN, S. (2003). “Tourism Clustering \& Innovation”, European Tourism Research Institute, MidSweden University, Sweden.

- OECD Proceedings, 1999, "Boosting Innovation The cluster Approach" http://books.google.com.pe/books/about/Boosting_Innovation.html?hl=en\&id=Go0Q3GJjaCgC

- OPPERMAN, M. (1993). "Tourism Space in Developing Countries”, Annals of Tourism Research, Vol.20, $\mathrm{N}^{\mathrm{o}} 4$, pp.535-556.

- PORTER, M.E. “Clusters and the New Economics of Competition”, Harvard Business Review, Vol 76, Issue 6, Nov/Dec 1998.

- $\quad$ PORTER, M.E. The competitive advantage of nations. New York: Free Press. (1990)

- SIMMIE, J. and SENNETT, J. (1999). "Innovation in the London Metropolitan Region”, in Hart, D., Simmie, J., Wood, P. e Sennett, J., "Innovative Clusters and Competitive Cities in the UK and Europe", Working Paper 182, Oxford Brookes School of Planning.

- URL-1, http://www.businessmate.org/Article.php?ArtikelId=49 